Rostás, P. (2021): Saint Stephen's Hall (A Szent István-terem) Metszet, Vol 12, No 5 (2021), pp 22-31,

DOI: https://doi.org/10.33268/Met.2021.5.1

Received: 15 September 2021 Accepted:

21 September 2021 Published: 14 October 2021 Abstract: Restoration, Budapest, Hungary; Architect: Tibor Angyal. To mark the coronation of Franz Joseph as King of Hungary in 1867, Alajos Hauszmann was commissioned, following the passing of Miklós Ybl to expand and improve the Royal Palace on Castle Hill. The jewel of this project being Saint Stephen's Hall which, the culmination of works by leading artists of the time centred on a monumental fireplace executed in pyrogranite by the factory of Vilmos Zsolnay. This hall was destroyed at the end of World War II. Under the National Hauszmann Program this hall has been accurately restored to its former splendour under the guidance of architect, Tibor Angyal.

\title{
A SZENT ISTVÁN-TEREM REKONSTRUKCIÓJA
}

| BUDAVÁRI PALOTA, BUDAPEST

_A Budavári Királyi Palota krisztinavárosi szárnyát a barokk palotával összekötő déli nyaktag első emeletén volt az egykori Szent István-terem, amelynek rekonstrukciója az utóbbi idők egyik legnagyobb 11 figyelmet kapó múzeumi projektje volt. A terem egykori létrehozásának indokát és célját a Magyar Sion folyóirat I897-ben így foglalta össze: „A Szent-Istvánterem berendezésével a nemzeti történelem vonul be teljes pompájával a budai királyi várba. Hogy menynyi lesz ott a koronás apostoltól vagy annak idejéből származó emlék, mennyi csak korhü stílusban készült másolat, építészeti, festészeti ékesség, az teljesen mellékes; a fódolog, maga a lényeg, az, ami a teremnek a rendeltetése lesz. Ez pedig a monarchikus katholikus Magyarország ifjú éveinek a reprezentáltatása. Szent István királyi és apostoli mivoltának dicsérete.” [I] _A termet eredetileg Zsolnay Vilmos kívánta egészében magyaros majolikaburkolattal kivitelezni, ezt kérvényezte a királytól I897 tavaszán írt felségfolyamodványában, [2] amely valószínüleg mindjárt a világkiállításon való magyar részvételről hozott parlamenti döntés, I897. április I6. után íródott. Zsolnay Vilmos fia, aki éppen I897-ben lett cégvezető, I887-I888-ban közel-keleti utazást tett. Itt egy I70 darabos falicsempe-gyüjteményt és több ezer darabos iszlám kerámiagyűjteményt vásárolt. Útvonala az angol művész-gyüjtőkét követte, olyanokét, mint Richard Francis Burton müfordító és felfedező, vagy Lord Frederic Leighton festő, akik komoly arab csempegyüjteményre tettek szert. Leighton saját londoni házában, amelynek építésze George Aitchison volt, rendezte be a híres Arab Hall-t I877-I88I között, amelynek falait a damaszkuszi Szinán pasa dzsámi számára I586-I59I-ben épült palota csempéi borítják. Ebből a csempeanyagból Zsolnay Miklós is vásárolt. [3] Ez a közel-keleti majolikaburkolatos, a palermói La Zisa normann palota I2. századi enteriőrjét másoló, ugyanakkor Walter Crane antikizáló aranymozaik frízével díszített főúri enteriőr bizonyosan fontos ihletője volt Zsolnay tervének. 



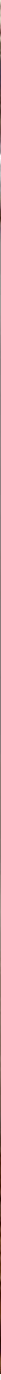

03 A homlokzati oldal az ablakokat keretező aranyhímzéses drapériával

04 A Zsolnay-kandalló

05 A Stróbl-féle Szent István-mellszobor

alkotója, hanem a Hauszmann-iroda egy másik tagja, vagy a Zsolnay gyár tervezője.

_A terem i898 májusában jóváhagyott tervei tulajdonképpen a falburkolat elrendezésének, méretezésének tervei voltak, amelyek a fából faragott ornamensek részleteit illetően sem a véglegesek. Még az I:I arányú műhelyrajzokon szereplő faragványok sem egészen úgy készültek el, ahogyan a rajzokon ábrázolták őket. _A terem „üzenetének” legfontosabb hordozója a fa falburkolatba illesztett tíz pirogránit tábla volt, amelyekre Árpád-házi királyok és szentek egész alakos képét festették és égették. A nyugati és a keleti ajtó fölötti, egyenként 3-3 táblából összeállított festménykompozíció István megkoronázását, azaz az államalapítást ábrázolta, valamint egy összetett jelenetet, amely egyszerre István és Adalbert püspök (más, korabeli leírások szerint Gellért püspök) hittérítő tevékenységét, és a székesfehérvári vagy még inkább a pécsi székesegyház megalapítását, azaz a vallásalapítást mutatta be. A festő, Roskovics Ignác alapos történeti és művészettörténeti stúdiumokat folytatott; a Nemzeti Múzeum régiségtárának darabjai mellett a megkoronázás-jelenet bal oldali tábláján kevésbé ismert történeti figurákat is megjelenített, mint Ceba nádorispán és Kujár országbíró.

__A Zsolnay gyár által készített kandalló övpárkányán elhelyezett Szent István-büsztöt Stróbl Alajos mintázta meg. Érdekesség, hogy alig néhány hónappal a mellszobros tervváltozat elkészülte előtt adták át a Szent István Társulat székházát a Szentkirályi utcában (ma a Pázmány Péter Katolikus Egyetem jogi karának épülete), amelynek homlokzatát Holló Barnabás egész alakos szobra díszíti. [6] Holló szobrán Szent István mint egyházalapító jelenik meg: az apostoli kettős keresztet tartja baljában. Holló és Stróbl Szent Istvánjának feje erős hasonlóságot mutat, így feltételezhetjük, hogy a közterületen először ezzel a Hollóművel megjelenő Szent István-szobor hathatott Stróbl alkotására.

__i898. május 20-án ugyan szerződést kötöttek Zsolnay Vilmossal a pirogránit elemek gyártására, [7] és I898. július 2-án a Thék gyárral a famunkákra, de a Szent István-terem kivitelezése I898 második felében, [8] a tervek elkészülte után csak részben indult meg. Egyfelől Roskovics késlekedett a kartonok leszállításával, másrészt nem rendelték meg a textileket. Erre csak 899 márciusában és áprilisában került sor. I899. 

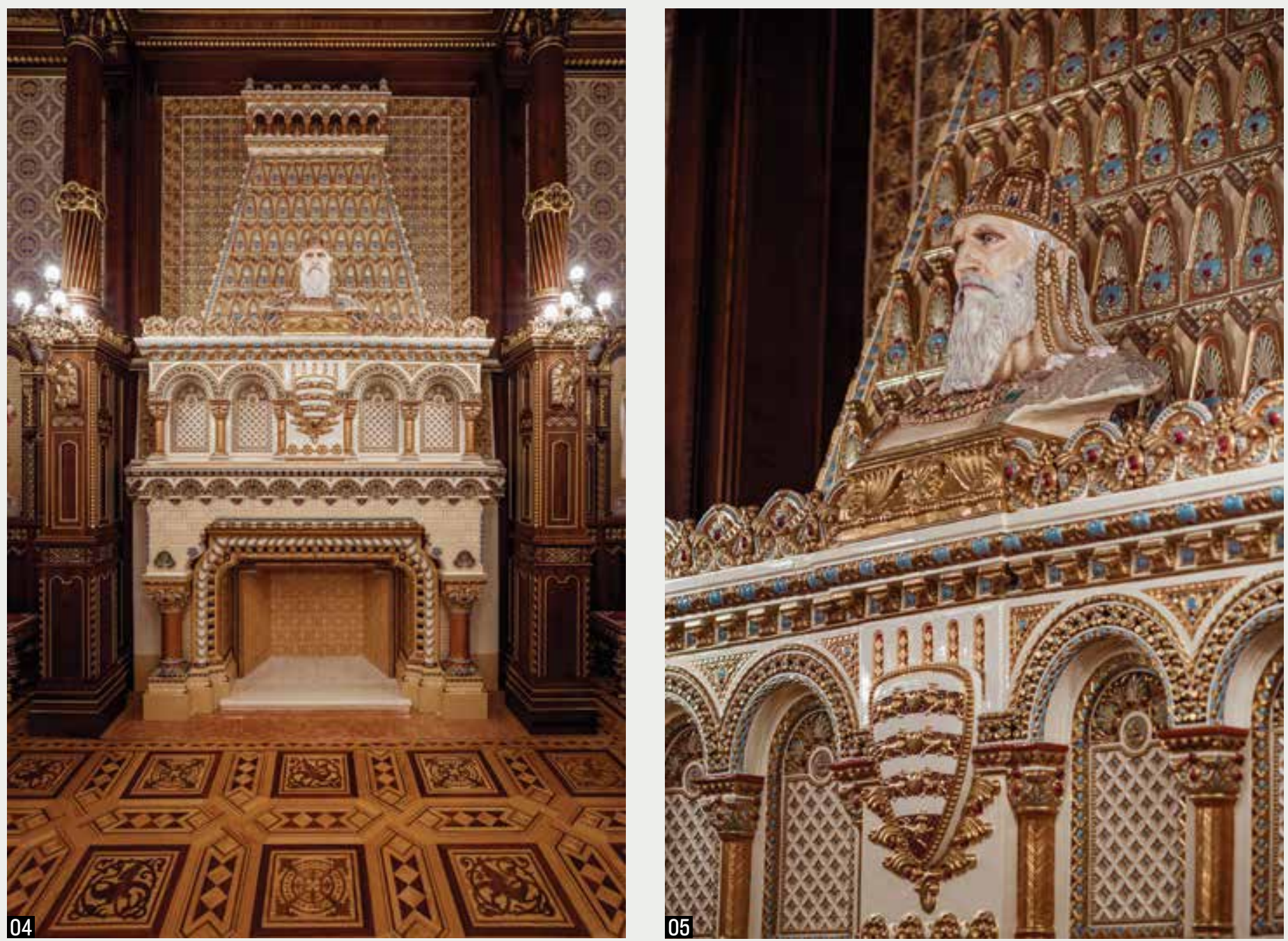

A terem újrateremtésekor az volt a cél, hogy minden benne legyen, ami 1902-ben benne volt, de semmi olyasmi ne legyen látható, ami nem volt látható 119 évvel ezelőtt, noha néhány berendezést be kellett építeni, ami a 20. század elején nem volt. A palota dísztereinek többségét légfütéssel látták el, ezért a teremben most is az eredeti szellőzőrácsok és a kandalló szolgálnak e célra, a karnis takarásában újabb elszívókkal. Az aspirációs füstérzékelő hat helyen szívja be a helyiség levegőjét, ennek gerincvezetéke a díszmennyezet és a födém közötti szűkös térben húzódik, és a fagerendák virágfaragványainak közepén, egy-egy mindössze $3 \mathrm{~mm}$ átmérőjú furaton át lélegzik. A tűzjelző a konzolasztal lapja alól vetíti fényét a padlóra. A biztonsági kamerák a teljes teret belátják, mégis sikerült úgy elrejteni azokat, hogy még a pontos helyüket ismerve sem vehetők észre. Az ablakbélletek lábazatában diófa ajtócskák mögött kaptak helyet a konnektorok. A terem eredeti, régies hatása így lehet teljes. | Angyal Tibor építész, az újjászületett Szent István-terem tervezője

március I8-án döntöttek arról, hogy a bemutatott minták alapján a Haas Fülöp és fiai céggel készíttetik el a falkárpitot, kisebb módosításokkal elfogadva a cég mintadarabját és a méterenkénti 90 forintos árat. Haas riválisa az orsz. magy. kir. Selyemtenyésztési Felügyelet által beajánlott vimpáci (Wimpassing an der Leitha, Burgenland, Ausztria) selyemgyár volt, amely azonban nem tudta előállítani az előírt minőségü, aranyfonalas brokátot.

__A nagyobb problémát a hímzett textilek megrendelésének csúszása jelentette. [9] A textileket és a kárpitos munkákat - ide értve a bútorok favázát is! - a Gelb M. és fiai cégtől rendelték meg. E vállalkozás kiváló francia kapcsolatokkal rendelkezett: a királyi palota építészirodája hiába vette fel egy esetben a francia gyártóval közvetlenül a kapcsolatot, magasabb áron tudta csak beszerezni a kívánt textilt, mintha a Gelb cégen keresztül vásárolt volna ugyanattól a gyártól. [10] Gelbék a Szent István-terem esetében is egészen biztosan külföldről hozatták be az alapanyagokat, sőt, feltételezhető, hogy az aranyhímző munkák is külföldön készültek. A Gelb M. és fiai cég megbízásáról azonban csak az I899. április 22-i várépítési bizottsági ülésen határoztak, és csak május 29-én kötötték meg a szerződést. [II] A késlekedő megrendelésnek tudható be, hogy a párizsi világkiállításra a hímzett bársonyhuzatos ülőbútoroknak valószínúleg csak egy része készült el: egy karosszék és egy taburet.

_Ugyancsak későn, I899. június 22-én rendelték meg a Kissling Rudolf és fia cégtől a világítótesteket. [12] Ezzel magyarázható, hogy a Thék gyárban, I900 februárjában felállított szobában még nem volt ott a kandalló két oldalán, és ezzel átellenben, a tükörfal mellett az összesen négy aranyozott bronz falikar.

_. A párizsi világkiállítás előtti hazai bemutatón az intarziás parketta sem volt még készen. A Neuschlosz Ödön és Marcel cég ajánlatát az I899. május 26-án 


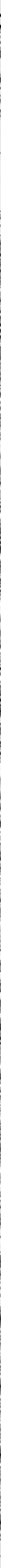

06

06

Az északi fal rekonstrukciós rajza

tartott építési bizottsági ülésen fogadták el, a szerződést pedig csak I899. június 22-én kötötték meg. [13] _AZsolnay gyár sem tudta teljesíteni teljes egészében a vállalását, hiszen a fa falburkolat felső, törpeoszlopokkal tagolt sávjának majolikabetétei a két rövid oldalon az ajtótól délre eső falburkolatban, illetve az ablakok oldalán még a párizsi világkiállításon sem voltak behelyezve!
_A terem az I900-as párizsi világkiállításon sikert aratott: a világkiállítás Grand Prix-ját kapta Hauszmann Alajos, valamint a Jungfer Gyula és a Neuschlosz Ödön és Marcel cég. Aranyérmet nyert a Gelb M. és fiai, a Haas Fülöp és fiai és a Kissling Rudolf és fia cég, a közreműködők között a Thék gyár igazgatói. Bronzérmet kapott Szikorszky Tádé, a Zsolnay gyár 
A Nemzeti Hauszmann Program keretében valósult meg a Budavári Palota déli összekötő szárnyának történeti átépítése és a Szent István-terem múemléki rekonstrukciója. A terem a déli összekötő szárny 1. emeletén megtalálható, nagyságrendileg 70 m²-es tér. A Szent István-terem müemléki rekonstrukciója mintegy hat évet ölel fel, egészen 2015-re nyúlik viszsza a terem visszaépítésének kezdete. A projekt vezetésével 2019 januárjában bíztak meg. Óriási megtiszteltetésnek és szakmai kihívásnak éltem meg a felkérést, bár akkor még nem tudtam, hogy igazán mire is vállalkoztam.

Projektvezetőként napi szinten koordináltam, felügyeltem és irányítottam a folyamatokat. Az évek során számos szakértővel, tervezővel, gyártóval és kivitelezővel ismerkedhettem meg. Az újjáépítés résztvevői a munka során igen jó csapattá álltak össze, melyre nagy szükség volt, hiszen a rekonstrukció hatalmas szakmai megmérettetésnek bizonyult. Elődeink magasra tették a mércét, hiszen ami a századfordulós mesterembereknek természetes volt, az egyáltalán nem volt az napjainkban.

A projekt során számos kihívással és nehézséggel néztünk szembe, de örömteli az érzés, hogy mindenre sikerült megoldást találni. Hogy a terem sikeresen újjászületett, annak kulcsát a csapatmunkában látom, hiszen mit ér a sok tudás és ismeret, ha nincs mellette a kéz, amely megvalósítja; de ugyanúgy mit ér a szorgalmas munka, ha nincs mögötte az az ismeret, a tudás, amely a kutatások, tudományos háttéranyagok összeállításából származik.

Ha az elkészült terembe lépek, büszkeség tölt el. A sikerre a legnagyobb bizonyíték, hogy az idelátogatók az elismerés hangján szólnak, és lenyügözi őket a varázslatos terem.

| Kapitány Dóra projektvezető, Várkapitányság Nonprofit Zrt.

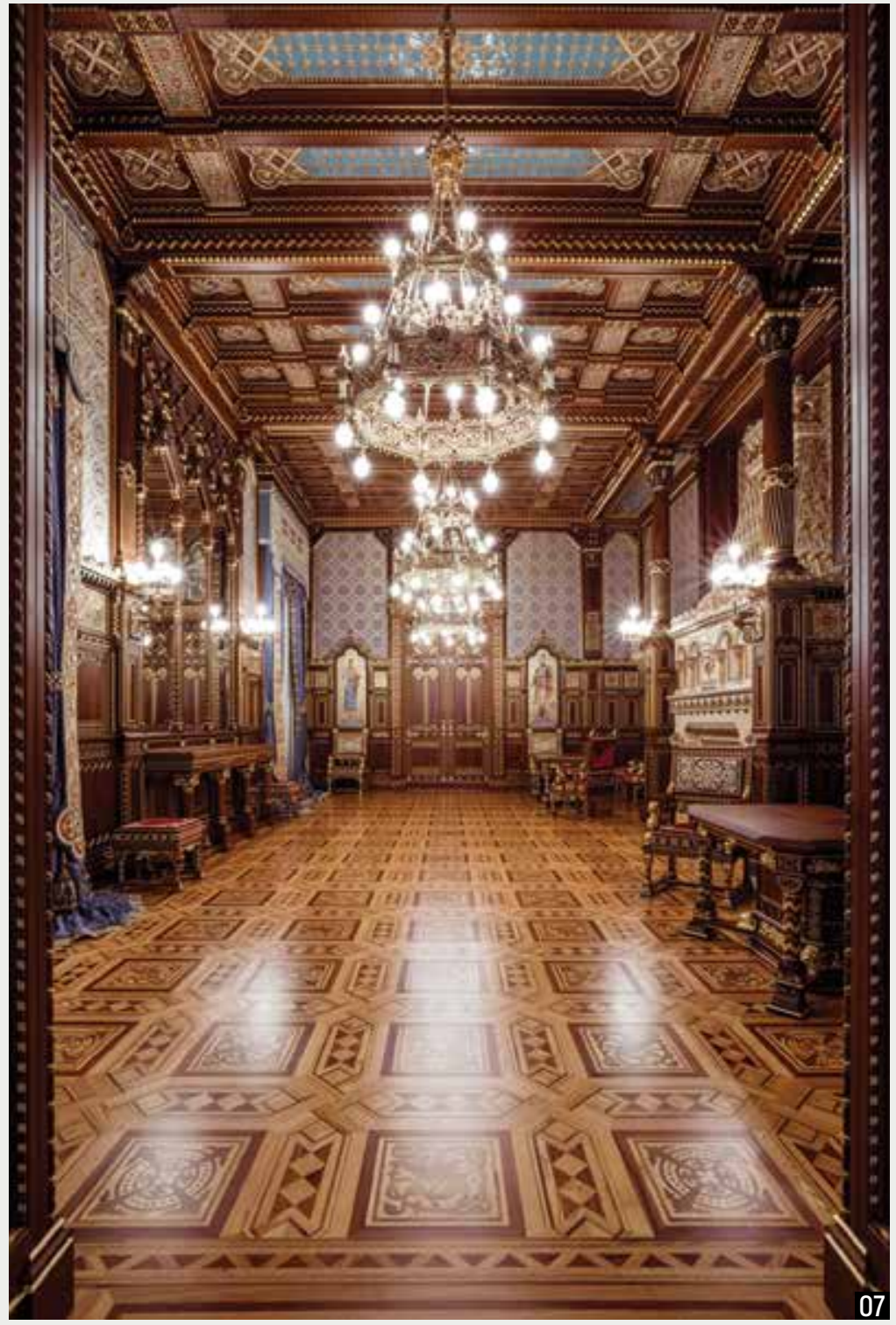

kötődik. A budapesti munka, ellentétben a szerényebb követelményeket támasztó Niederdeutsches Zimmerrel, technikailag bravúros teljesítmények sorát vonultatta fel minden müfajban, és a kivitelezést az akkor európai rangú magyar iparművészet vezető cégeinek, illetve a textil esetében francia és itáliai specialistáknak engedték át.

_A Szent István-terem a II. világháborúban minden bizonnyal kiégett, falburkolata valószínűleg itt semmisült meg. Nagy kérdés azonban, hogy mi történt a kerámiaelemekkel és a mobiliákkal, ide értve a függönyöket is. Gyanúnkat, hogy a mozdítható tárgyak esetleg még az ostrom előtt kikerültek a teremből, arra alapozzuk, hogy az Iparművészeti Múzeumban fennmaradt az egyik függöny jobb oldali függőleges sálja, amelyet 198Iben ajándékba kapott a múzeum Martin Ferencné, gróf Bethlen Klárától. [16]

A terem falszövet anyagából négy töredék maradt fenn: - Egy Györgyi Géza leszármazottjánál; ez azzal a bemutató darabbal azonosítható, amelyet a Haas cég prezentált a művezetésnek, és amelyen még kis korrekciót kértek Hauszmannék. Ez a módosítás nevesíthető is: a korona és a körülötte lévő koszorú kétféle aranyozását cseréltették meg, úgy, hogy a korona legyen óarany, és a körbefutó ornamenssáv legyen világosabb aranyszínü.

Egy 27 x I0 cm nagyságú töredék, amely feltehetően az elpusztult teremből magából származik, egy budapesti magángyűjtőnél maradt fenn.

Egy darab, minden bizonnyal a Haas cég egykori túlgyártásából, eredeti friss színeit megőrizve került az I970-es években az Iparmủvészeti Múzeum tulajdonába. [17]

Egy pedig a Váci Egyházmegyei Gyüjteményben maradt fenn, ahol az állandó kiállítás részeként van kiállítva az a szövetdarab, amelyet IV. Károly koronázásakor használtak a Szent Korona alátét drapériájaként.

_Ezenfelül fennmaradt a Szent István-terem falszövetének egyszerübb technikával kivitelezett, de megjelenésében nagyon hű másolata. A Lendvay utcai Groedel Ármin-villa földszinti lakásának egyik termét ugyanis az erdővásárlásairól elhíresült Máramaros megyei fakereskedő I904 körül a Szent István-terem ihletésére, 


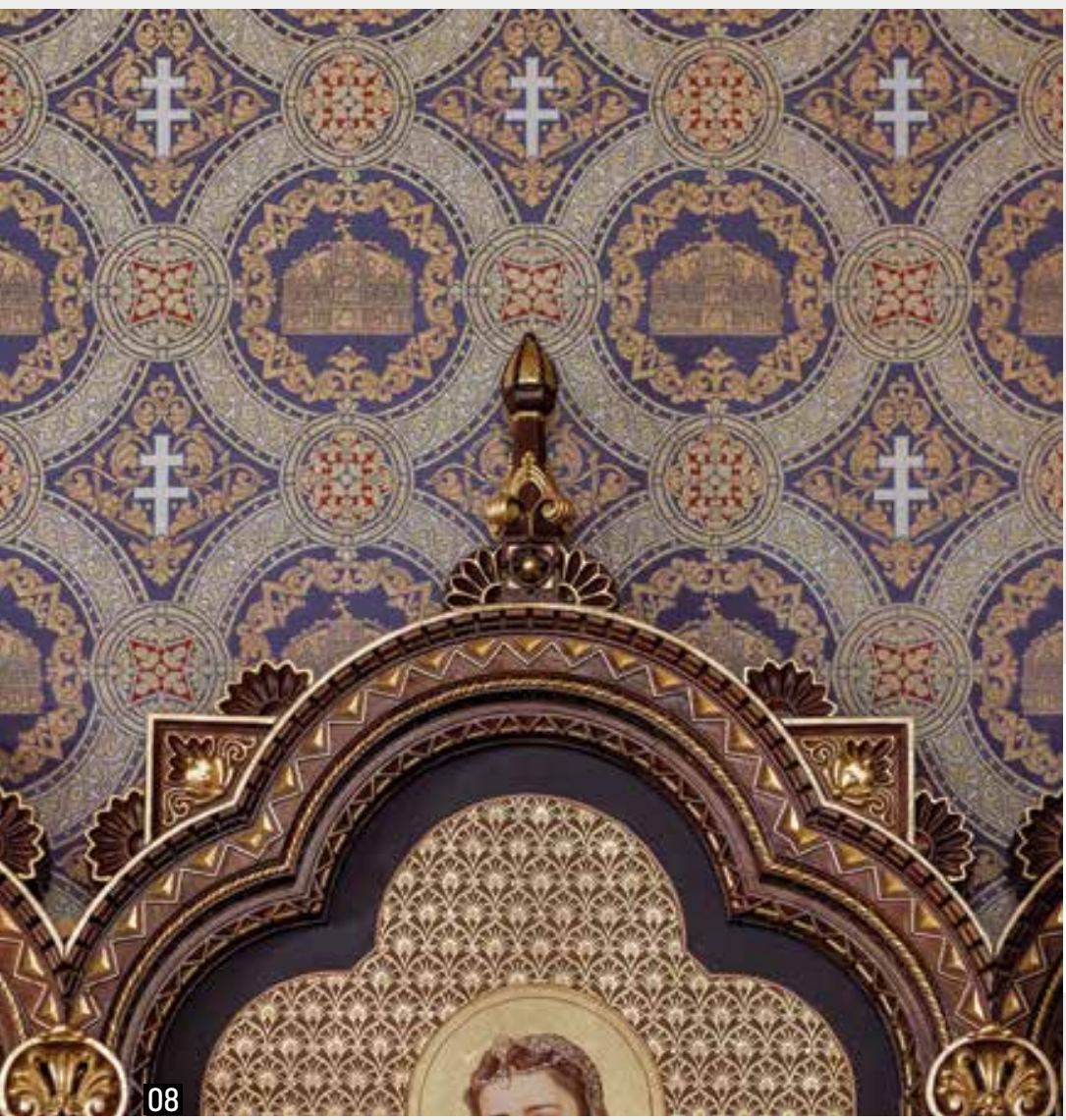

07

\section{Az intarziás,}

sárkánymotívumokkal

díszített parketta

08

A díszes faragás egy

részlete...

09

...és annak rekonstrukciós

terve

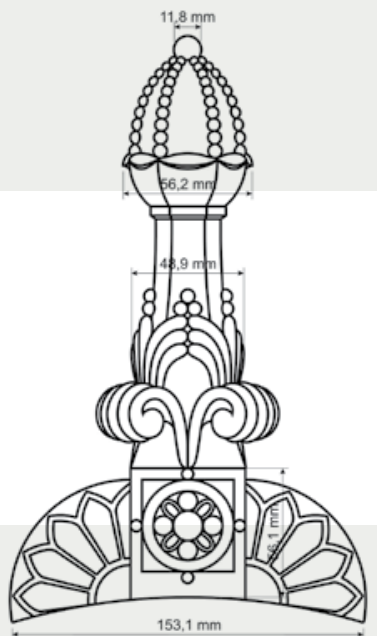

annak átirataként rendezte be, vélhetően nem függetlenül feudalizálásától, azaz bárói címének elnyerésétől. Ebben a teremben az eredeti lanszírozott és brosírozott technika helyett tisztán lanszírozással másolták le a palotabeli eredeti tapétát.

__Hauszmann egykorú leírását, mely szerint a Haas cég Milánóból hívott szakmunkásokat a falszövet legyártásához, [9] talán úgy kell értelmeznünk, hogy az aranyosmaróti (ma: Zlaté Moravce, Szlovákia) szövőgépre Itáliából hoztak brosírozó kiegészítő szövőládát, amelyet a Szent István-teremhez szükséges anyagmennyiség legyártását követően minden bizonynyal vissza is szállítottak. A Haas cég azonban nem állt le a szövet gyártásával, hiszen a mintát a meglévő finom alapanyagokból tisztán lanszírozással is megfelelő, szemmel látható minőségi különbség nélkül le tudták gyártani.

_A Szent István-terem Zsolnay gyárban készült elemei közül fennmaradt a kandallóra helyezett Szent Istvánbüszt másodpéldánya, a kandalló csempéi és a falburkolat betétei közül több darab, valamint a királyképek közül is ötféle ábrázolásból összesen nyolc próbaégetés, melyek között az I. Bélát ábrázoló tábla egész alakos, a többi fél- vagy háromnegyed alakos ábrázolás.

_-Az Árpád-házi királyokat és szenteket ábrázoló Roskovics-féle képsorozat olaj-vászon kartonjai fennmaradtak a Magyar Nemzeti Galéria gyüjteményében. [I8]

_A Szent István-terem ikonográfiáját adó Roskovicsféle olaj-vászon festménysorozatot a Zsolnay gyár által szerződtetett fiatal festőművészek, Nikelszky Géza és Dařilek Henrik ültették át a kerámiakép műfajába. Ez az aktus komoly, akadémiai előképzettséget feltételezett, ugyanakkor nagyon fontos tisztázni, hogy itt mégis alkalmazott művészetről, iparművészetről volt szó, és nem képzőművészetről. A mostani rekonstrukció ellenzői felvetették, hogy miért nem nagy festők elveszett, és csak fényképről ismert alkotásainak rekonstruálására költ a magyar állam. A válaszhoz azt kell tisztázni, hogy az iparmüvészetbe átültetett grand art éppen a megismételhetetlen jelleget, az egyediség auráját nélkülözi, ennél fogva szellemi veszteség nélkül reprodukálható, legyen szó akár egy tintatartóról, amely Michalengelo Medici-kápolnájának meztelen 

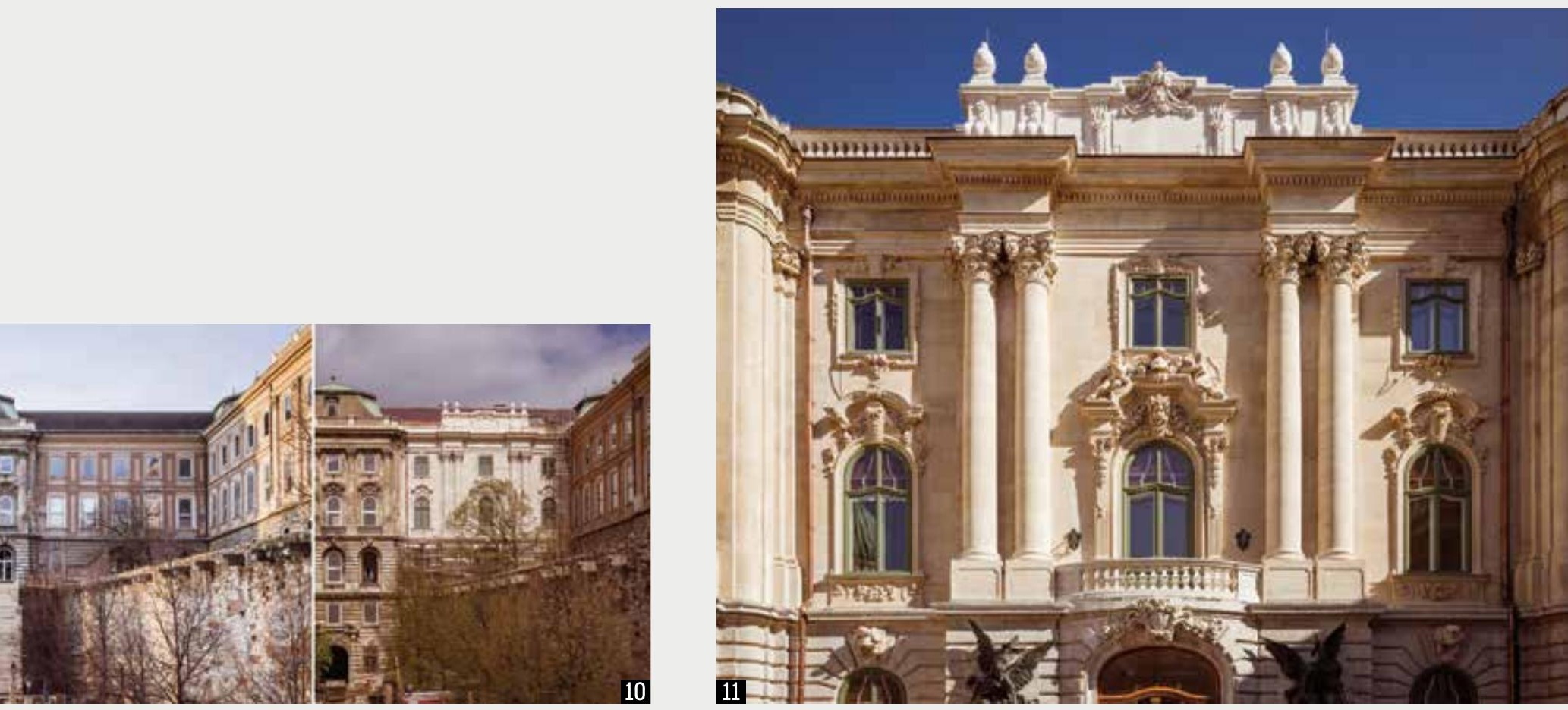

\begin{abstract}
A beruházás kivitelezési szakaszának megkezdése előtt szondázó, majd a nem várt jelentőségú eredmények hatására teljes feltáró kutatások készültek Bozóki Lajos múvészettörténész vezetésével. Ezek a Szent István-terem esetében ugyan nem hoztak érdemi eredményt, de annak környezetében, az épületszárny többi rekonstruált részében annál inkább. A földszinten, az első és második emeleten háború előtti, festésmaradványokat is tartalmazó vakolat- és stukkótöredékek kerültek elö, illetve egyéb elpusztult szerkezetek (faburkolat, korabeli villanyhálózat) lenyomatát sikerült azonosítani. Ezek a hiteles részletformák lemásolását tették lehetővé a rekonstruált északi folyosón, valamint az eredeti tervektől eltéröen megvalósult állapot rekonstrukciójának sarokkövei (pl. az eredeti faltükrök megvalósult osztása).

A földszinten elfalazásból elókerült az áthajtó egyik oszloppárja is, ami a már megtervezett beltéri kőelemek módosításához vezetett. Így a több dobból tervezett oszloptörzsek végül egész kőelemekből lettek kimunkálva, a tagozatokat a meglévőkről lehetett lemásolni, a kísérő pilaszterek tervezett kőanyaga pedig vakolatra változott. A második emeleten feltárt barokk kori ablaknyílás miatt a tartószerkezeti rendszeren is változtatni kellett. A pinceszinten a kivitelezés során vált ismertté az egykori kocsizórámpa és egy elépített kőlépcső. Régészszakmai kívánságra itt egy szakaszon a középkori palota faláról lebontották a barokk kori köpenyfalat.

Érdekes volt a források részletesebb értelmezése is, az az iterációs tervezési munka, ami a kivitelezéssel párhuzamosan, időnként csak pár nap előnnyel folyt. Az északi folyosó faburkolatai és ajtói például így lettek pácolt tölgy helyett fehérre festettek.
\end{abstract}

| Szegổ Tamás múemlékvédelmi referens, ÉMI Nonprofit Kft.

rabszolgája sokszorosításával készült, vagy egy Goyakarton után szőtt gobelinről.

_A fémes munkákat is megkönnyítette, hogy a fent már említett Groedel-villában a Szent István-terem falikarjainak pontos mását találtuk, de a budavári enteriőrben egykor elhelyezett nyolcszögletű csillárnak a hatszögletű változata is ebben a villa-enteriőrben függ.

Az aranyozott bronz ajtó- és ablakkilincsek és zsanérok újragyártását az Iparművészeti Múzeum Ötvösosztályán őrzött eredeti darabok tették lehetővé. _.Az archív fényképeken csak erős rövidülésben látható intarziás parketta visszafejtésében felbecsülhetetlen segítséget jelentett a Szent István-terem Groedel-villabeli parafrázisának parkettája, amely egy apró részletet, illetve némi méreteltérést leszámítva megegyezik a Szent István-terem elpusztult, a Neuschloss Ödön és Marcel parkettagyár által készített eredeti parkettájával.

_-A visszatervezés munkájában Angyal Tibor építész felhasználta még az egykori múemlékvédelmi tervtárban, valamint a Janus Pannonius és a BTM Kiscelli 06 Múzeumban fennmaradt archív terveket, melyek között 09 a kandallóról és az ajtószárnyról I:I léptékű terv maradt fenn, azonban ezeket is kritikusan felül kellett vizsgálni és korrigálni a ténylegesen megvalósult terem nagyon jó minőségű archív fényképei alapján. 


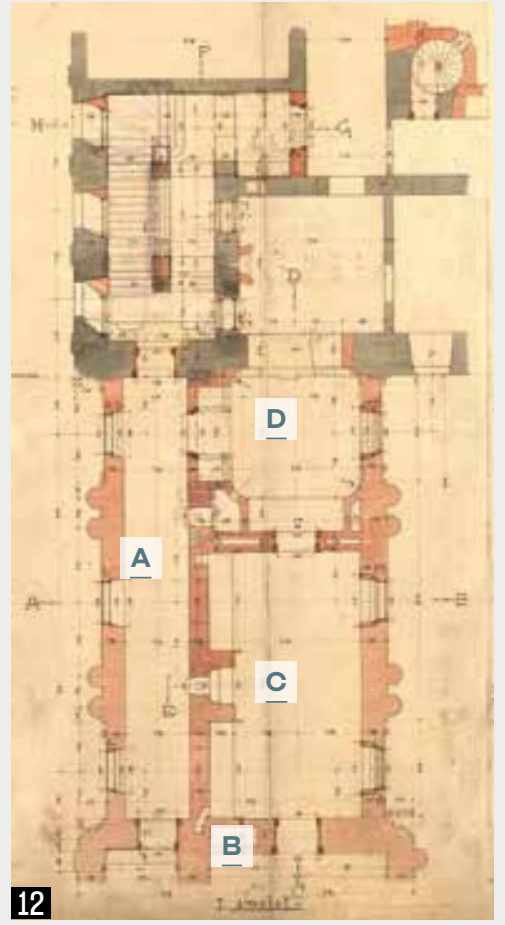

\begin{tabular}{l|l} 
A & Összekötő folyosó \\
B & Cercle-terem \\
C & Szent István-terem \\
D & Öfelsége előszobája
\end{tabular}

10

A nyaktag déli homlokzata

a felújítás előtt és után

11 Az északi, udvari homlokzat

12 Archív alaprajz

(forrás: Építészeti Múzeum)

13 A mennyezetterv rekonstrukciós rajzának részlete

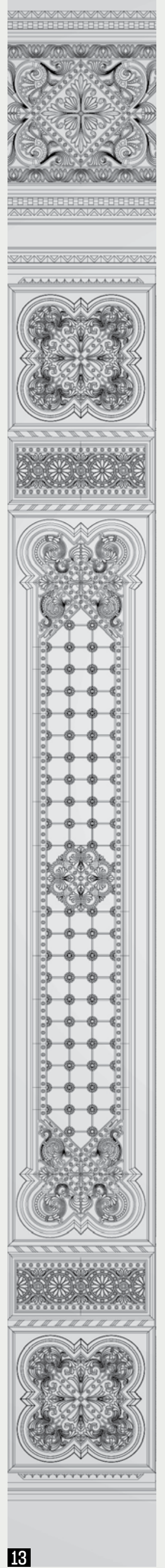

IRODALOM / REFERENCES

[1] Magyar Sion, 1897, p 880.

[2] MNL-OL, K26, miniszterelnökségi iratok, 133/1898.

[3] Gerelyes, Ibolya-Kovács, Orsolya: Egy ismeretlen orientalista, Zsolnay Miklós keleti kerámiagyújteménye, Pécs 1999, p 13.

[4] MNL-OL, K26, miniszterelnökségi iratok, 133/1898.

[5] Budapesti Hírlap, 1897-10-30, p 6.

[6] Új Idők, 1897, p 170.

[7] II/3/c a királyi várépítési bizottság iratai, számadások, 31 doboz, 223/1901.

[8] II/3/c a királyi várépítési bizottság iratai, számadások, 30 doboz, 72/1901.

[9] „A királyi vár belső kiképzése és iparművészeti felszerelése”, Budapesti Építészeti Szemle, 1903 pp 248-253.

[10] BFL, II/3/c királyi várépítési bizottság iratai, számadások, 39 doboz, 296/1902.

[11] II/3/c a királyi várépítési bizottság iratai, számadások, 36 doboz, 88/1902.

[12] II/3/c a királyi várépítési bizottság iratai, számadások, 35 dob0z, 364/1901.

[13] II/3/c a királyi várépítési bizottság iratai, számadások, 47 doboz, 262/1903.

[14] Malkowsky, Georg: „Der Saal des Heiligen Stephan in der ungarischen Abteilung” in Die Pariser Weltaussttellung in Wort und Bild, Berlin 1900, pp 350.

[15] Klein, Malte: Das Kunstgewerbemuseum Flensburg, Konzeption und Funktionen eines Museums im Kaiserreich, Kiel 2007, pp 160-168.

[16] Iparművészeti Múzeum Itsz 81,140.

[17] Iparmúvészeti Múzeum, Itsz 75,35,1.

[18] MNG Itsz 91,1 - 10 T. 